\title{
Highlights of the professional activities of Nikolay Ivanovich Pirogov before and after his professoriate in Saint Petersburg (1841-1860). Part I
}

\author{
I. F. Hendriks ${ }^{1 *}$, J. G. Bovill1, D. A. Zhuravlev², F. Boer ${ }^{1}$, E. S. Houwaart3, \\ P. C. W. Hogendoorn ${ }^{1}$, I. V. Gaivoronskii 4 \\ ${ }^{1}$ Leiden University Medical Center, Leiden, Netherlands \\ 2Military Medical Museum, St. Petersburg, Russian Federation \\ 3University of Maastricht, Maastricht, Netherlands \\ ${ }_{4}^{4}$ S.M. Kirov Military Medical Academy, St. Petersburg, Russian Federation
}

This article is the first part of two articles on Nikolay Ivanovich Pirogov. In this article we will discuss how Pirogov developed in his early professional career his unique scientific attitude toward medical problems. He extended this scientific view already before his appointment as Professor of Applied Anatomy and Hospital Surgery at the Medical-Surgical Academy and chief surgeon of the Second Military Landforce Hospital (with 10oo beds) in 1841. After his resignation as Professor in 1860 and during his retirement he used his views and skills towards the management of mass casualties during wars or others, which eventually developed into the International Red Cross.

In the second article "Nikolay Ivanovich Pirogov as an innovator in anatomy, surgery, and anaesthesiology." we will highlight his professional career as an anatomist, surgeon and anaesthesiologist. The authors of these two parts want to emphasize that these two articles are an extract from previously published extensive articles related to Nikolay Ivanovich Pirogov. You can find these articles in the reference list under the name of the first author [20-25].

Key words: Russia - (pre1917), Nikolay Pirogov, history, medicine, Red Cross.

\begin{abstract}
Основные вехи профессиональной деятельности Николая Ивановича Пирогова в СанктПетербурге (1841-1860). Часть I

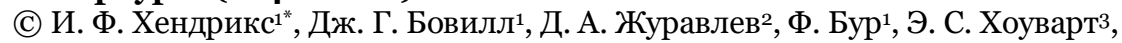

П. С. У. Хогендурн ${ }^{1}$, И. В. Гайворонский 4,2020

${ }^{1}$ Медицинский центр Лейденского университета, Лейден, Нидерланды

${ }^{2}$ Военно-медицинский музей, Санкт-Петербург, Россия

зУниверситет Маастрихта, Маастрихт, Нидерланды

4ФГБВОУ ВО «Военно-медицинская академия им. С.М. Кирова» Минобороны России, Санкт-Петербург, Россия

Данная статья является первой частью двух статей о Николае Ивановиче Пирогове. Авторы статьи ведут дискуссию о том, что Н.И. Пирогов уже в ранней профессиональной деятельности развил свое уникальное научное отношение к медицинским проблемам. Он расширил научный подход к медицине еще до своего назначения профессором прикладной анатомии и госпитальной хирургии в Медико-хирургической академии и главным хирургом Второго военного госпиталя сухопутных войск (на 1000 коек) в 1841 году. После отставки с поста профессора и ухода на пенсию в 1860 году, он использовал свои взгляды и навыки для управления лечебной деятельностью во время войны, на основе его деятельности в конечном итоге был сформирован Международный Красный Крест.

Во второй статье «Николай Иванович Пирогов как новатор в анатомии, хирургии и анестезиологии», авторы уделяют большое внимание его профессиональной карьере анатома, хирурга и анестезиолога. Авторы этих двух частей хотят подчеркнуть, что эти две статьи являются выдержкой из ранее опубликованных обширных статей, касающихся Николая Ивановича Пирогова. Читатели могут найти эти статьи в списке литературы под именем первого автора [20-25].
\end{abstract}

Ключевые слова: Россия (до 1917 г.), Николай Пирогов, история, медицина, Красный Крест.

\section{Introduction}

*Corresponding author:

Inge F. Hendriks, MA,

Department of the Executive Board, Post zone H-01-46, Leiden University Medical Centre, PO Box 9600, 2300 RC Leiden, The Netherlands

E-mail: i.f.hendriks@lumc.nl
From the IX to the XVIII century (over 10 centuries), Medicine in Russia went through a long and complicated path. After the conversion of Kievan Rus' to Byzantium Christianity, monks provided basic medical care in the monasteries along with folk healers [30, 32, 55]. Most of the population in Russia did not have access to qualified medical care and relied on traditional folk remedies. Qualified medical care was received 


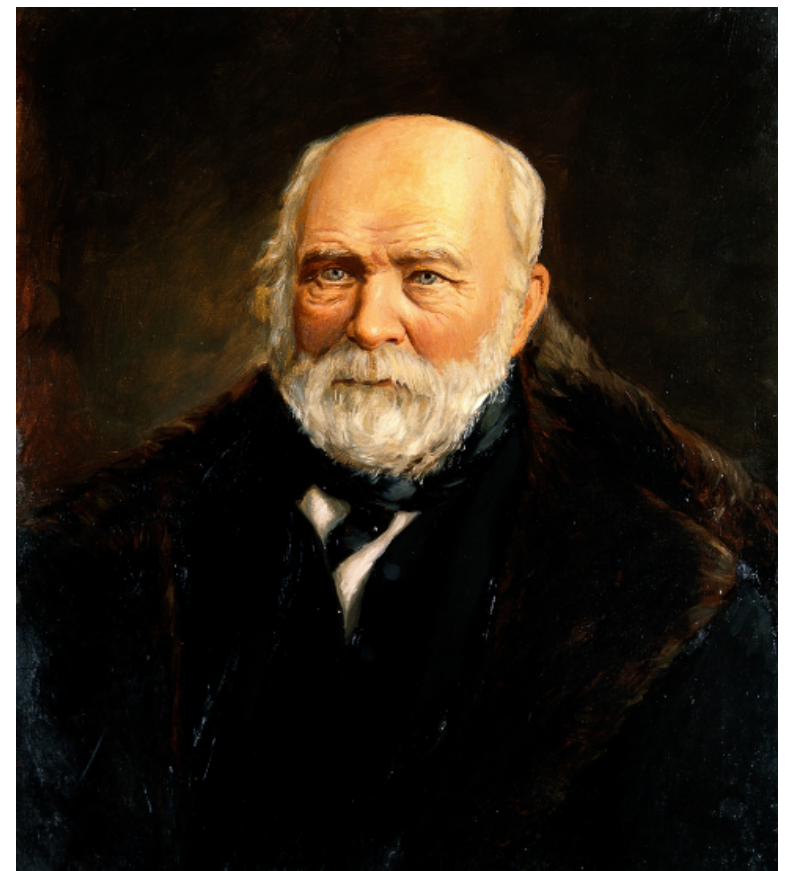

Fig. 1. Portrait of Nikolay Ivanovich Pirogov. Oil on canvas, artist and date unknown. Wellcome Library, London, Image Voo180o7. Reproduced with permission.

only by rich people, which was provided by foreign physicians.

Tsar Mikhail Fyodorovich (1613-1645), the first reigning Romanov, instituted improvements in social welfare and healthcare $[5,53,55]$. During the reign of Peter the Great and his successors most significant achievements in the field of public health in Russia took place $[11,36,54]$.

It was not a Tsar or Tsarina but Nikolay Ivanovich Pirogov (1810-1881) a well-educated Russian physician reorganised the medical education, introduced a new curriculum for medical students. He extended surgery from a craft to a science and contributed beyond the boundaries of surgery. He raised the medical skills in Russia to an equal level of the advanced countries of Europe, which took Russia 150 years since Peter the Great $[52,56]$.

\section{Nikolay Ivanovich Pirogov (1810-1881)}

Nikolay Pirogov was born 13 (25) November 1810 (Fig. 1) in Moscow as the thirteenth child [50, 52]. The family had friends of different plumage like the physician G.M. Berezkin of a Moscow educational home. Berezkin attracted the young Pirogov with historical stories about Russia. The retired vaccinator A.M. Klaus showed him a microscope. Efrem Osipovich Mukhin, surgeon, anatomist, physiologist, and traumatologist, Professor and Dean of the Medical Faculty of the Imperial University of Moscow, but also a valid state councillor left the most impression.

During his childhood Pirogov played "war game" and "the doctor" at home. The last one was very significant and it lifted the veil of his future. One of his older brothers was bedridden with rheumatic fever. Several doctors looked after his brother but nothing helped. Then the family called in Efrem Osipovich Mukhin. The young Nikolay watched and observed the handlings accurately and closely. His brother started to recover after just a few days. Nikolay started then to imitate Mukhin. The people at home and even his cat, dressed as a woman, were his patients. He was 13 years 1814 as he as a medical student entered the Moscow University [52]. Pirogov graduated at the age of seventeen at the Moscow University but was very unsatisfied $[50,52]$. He did not consider himself as a physician, because he did not carry out one single operation, a bloodletting, pulling any teeth, dissect a single dead body or sectioned a single muscle. Pirogov stated that "...it was a rather theoretical education on the basis of textbooks from the 1750s..."[50].

As a talented 17 years old student he was able to continue his study at the German-Baltic University of Dorpat (now Tartu in the Republic Estonia) with a scholarship. The aim of this study in Dorpat and a traineeship of two more years at foreign universities in Europe was to prepare him as a staff member at a Department of a Ministry or as a professor of a university $[50,52]$.

Students of the medical faculty in their first year at Dorpat were required to write an essay based on research on an allocated, contemporary topic [18]. Pirogov was allocated the topic ['What is observed when a large artery is ligated?'] The ligation of an artery in a patient with an aneurysm was a very new and potentially dangerous procedure at that time [15]. Pirogov's essay as the best assay won him the Gold Medal [18]. In 1829 the Medical Faculty freed him from compulsory attendance at some lectures so that he could work on his doctoral thesis, the feasibility of treating aneurysms of the inguinal artery by ligation of the abdominal aorta $[18,49]$.

Pirogov was aware of several publications on the topic, including those by the French surgeons Jacques Lisfranc de St. Martin and Alfred Velpeau, and Sir Astely Cooper. In 1808 Cooper had attempted ligation of the external iliac artery in a patient with an aneurysm and in 1816 he was the first to ligate the abdominal aorta for treatment of an iliac aneurysm [2, 3, 8]. Pirogov wrote “...This interested me with respect to both its surgical and physiological aspects..."[52] Although the patient died "... It remained to be decided whether, in fact, such an operation could be carried out with a hope of success..."[52] In his animal experiments Cooper had only investigated the effects of ligation of the aorta in mediumsized dogs [37]. Pirogov suspected that the results of such an operation might depend both on the size of the animal and the species studied. He, therefore, set out to investigate this in a series of animal experiments. His objectives were:

- to get a clear and accurate insight into the structure and function of the abdominal aorta. 
- to perform a thorough study of the position of the abdominal aorta in relationship to the surrounding organs.

- to get a detailed understanding of the circumstances leading to collateral formation after ligation of the abdominal aorta.

- to determine the impact of the ligation on the artery and the surrounding tissues, on the lateral branches of the aorta, and finally which general changes the body underwent.

Pirogov spent long hours in the anatomy theatre conducting 28 experiments involving dogs, cats, sheep or calves; the results of which formed the core of his doctoral thesis [37]. In his zeal and youthful passion he was indifferent to suffering and operated on both dead and living animals to learn as much as possible about their anatomy and how they reacted to ligation of the aorta [50].

However, based on the findings from his animal experiments and what others had observed in patients in whom this procedure was performed, Pirogov had considerable reservations about the safety of this procedure in humans. He was concerned that much of the available evidence came either from a limited number of animal experiments or from findings based on autopsies in humans. He remarked that the ligation of the abdominal aorta in small animals is more likely to be successful because the ligature is almost always placed between the two mesenteric arteries and secondly because the anastomoses from the aorta to the lower parts of the body (i.e. greater ability to form a collateral circulation) plays a much more important role in the smaller animal. In larger animals the sudden obstruction of the aorta beneath the mesenteric arteries is seldom associated with a successful outcome.

Pirogov successfully defended his thesis 'Num vinctura aortae abdominalis in aneurysmate inguinali adhibitu facile ac tutum sit remedium' and was awarded his doctorate in April 1832 [49]. He published a German translation in 1838 [39, 40]. A Russian translation was published much later, in 1957 9. Pirogov added an appendix to his thesis (not included in the German article of 1838 but it is in the Russian translation of the Latin thesis of 1957) in which he summarized the most important results of his latter experiments.

He opened his thesis with a quotation from François Magendie (1783-1855) [19, 31,57], a French pharmacologist and physiologist. Magendie wrote "...Expressing or believing an opinion in science without evidence is nothing else than ignoring the truth ..."[37] Pirogov included this quotation as it emphasized his core belief that in science nothing should be taken for granted, a principle that permeated his whole career and characterized his approach not only to science but to every aspect of his life. For him, like Magendie, “...Science is not built from what people think, but from what people have discovered ...”[37].

\section{Two-years post-doctoral study in Germany}

After gaining his doctorate Pirogov got permission from the Ministry of National Education (also named Ministry of Enlightenment) to travel to Germany to complete a further two years post-doctoral study of anatomy and surgery at the Charité Hospital in Berlin in 1833 [52]. During his first semester in Berlin he was assigned the following mentors;

- Professor Friedrich Schlemm for anatomy and for surgical studies on cadavers.

- Professor Johan Nepomuk Rust for clinical lectures.

- Professor Karl Ferdinand von Gräfe for ophthalmology.

- Professor Johann Friedrich Dieffenbach for surgery, specialized in plastic surgery and skin transplantation.

He also attended many of the lectures by the comparative anatomist and physiologist Johann Müller, who conducted demonstrations on animals (mainly frogs), often making use of a microscope.

Pirogov spent the summer of 1834 at the University of Göttingen where he attended lectures by Konrad Langenbeck, famous for his speed and precision as a surgeon. He taught Pirogov how to achieve the most efficient movements during surgery and how to use a scalpel "...do not pressure the scalpel but move it slowly, playing it as a bow over the violin..."[52] Pirogov understood that a fast and skilled surgeon was very important for saving the patient for pain and trauma. Even later when anaesthesia was introduced Pirogov wrote: “...a slow operation even using anaesthetics could be harmful to the patient, because of the prolonged anaesthesia and the trauma..."[42, 52].

Before Pirogov came to Germany he could not imagine that a skilled surgeon could doubt the importance of anatomy, but this was indeed what he found in Berlin. For Pirogov knowledge of anatomy was essential for a surgeon "... It is advisable that only someone familiar with the body, the position of the organs in their unaltered state and the painful changes, should operate on a person..."[37] and without a thorough knowledge of anatomy and physiology, surgery could never rise to the level of a science but would remain a craft.

The only surgeon in Berlin to perform surgical experiments on human corpses was professor Schlemm, who was convinced of the importance of anatomy for a surgeon. He allowed Pirogov to work with him on these experiments. The other person with whom Pirogov cooperated was the former midwife, madame Vogelsang, who was devoted to anatomy [52]. They spent long hours together in the Charité Hospital in Berlin, 
during early morning and late evening, when she taught Pirogov the intricacies of anatomy.

While Pirogov felt passionate that a good knowledge of anatomy was an essential prerequisite for a surgeon, he realized that a surgeon's approach to anatomy must differ from that of an anatomist or pathologist. Even though the anatomist has a thorough knowledge of the human body, the surgeon was the expert in the application of that anatomy. Pirogov pointed out that when the surgeon makes his incisions, he needs to have a detailed knowledge of the location of the various fascia, muscles, arteries, and nerves within the layers lying under his knife to avoid damaging them or at least causing minimum damage. He went on to say that none of the anatomical-surgical manuscripts that he had read reflected this opinion. He considered the papers published by French surgeon-anatomists such as Alfred-Armand-Louis-Marie Velpeau and Philippe-Frédéric Blandin to be incomplete because they did not show the brachial artery (a. brachialis) or the femoral artery (a. femoralis) in their manuscripts [38]. He advocated that the chair of surgical anatomy should be held by the professor of surgery, not by the professor of anatomy.

\section{Return to Dorpat}

In May 1835 Pirogov returned to Dorpat where Professor Moier asked him to join his department as extraordinary professor [52]. However, such an appointed need to be confirmed by the Ministry of National Education, necessitating Pirogov travel to St. Petersburg, then the capital of Russia. While he waited for the confirmation Pirogov gave over six weeks many anatomy demonstrations, held in the mortuary of the Obukhov Hospital. They were attended by 20 or more of his fellow surgeons and doctors from the Obukhov hospital and the Imperial Medico-Surgical Academy. He also gave a lecture to the Academy of Sciences 'About plastic surgery in general, and about rhinoplasty in particular'[58]. He used a face made of papier-mache to demonstrate the Indian rhinoplastic method as modified by Dieffenbach. During his career Pirogov carried out forty rhinoplasties.

Nikolay Pirogov spent eight hours each day carrying out and analysing anatomical experiments in addition to his clinical duties. During these experiments he made at least two or three drawings of his dissections as he believed that these would be useful to surgeons in helping them during operations in patients. One image represented the relative position of the fascia to the arteries, the second and third represent those of the muscles, veins and nerves. The branches of nerves, arteries, lymph vessels and glands as well as bundles of fibrous tissues were accurately reproduced in his drawings. These served to define the detailed topography of an area [1]. The result of these experiments was published, in black and white, in an extensively illustrated atlas of arte- rial trunks and fascia first in German in 1837, in 1838 in Latin [58] and in 1840 in Russian.[18] In it, he wrote: "...A real anatomical-surgical image must be for the surgeon what a map is for the traveller..."[58] The atlas was re-published with the permission of Pirogov by Julius Szymanowski in 1860 , who added one extra page, a drawing of the total body, and also coloured the arteries red and the veins blue [6o].

In 1837 Pirogov was given a grant to visit Paris, where he met several surgeons, among them Alfred-Armand-Louis-Marie Velpeau, a skilled surgeon and renowned for his knowledge of surgical anatomy. Velpeau was at that time reviewing Pirogov's publication 'Surgical Anatomy of the Arteries and Fasciae', to have it acknowledged by the Paris Academy [38, 52]. He praised Pirogov for his work on surgery and his research into facias and on his drawings. Pirogov was invited by the surgeon Jean Zuleman Amussat to his home where met fellow surgeons Astley Cooper, Dieffenbach, Roux and Lisfranc. During a discussion on the urinary tract, Amussat spoke of his conviction that the urinary tract in men was totally straight. Pirogov disagreed and told him about his findings in frozen corpses. They continued to disagree on this subject, so Pirogov showed them specimens that he had previously prepared to prove his findings. He also brought pelvis sections to prove the absurdity of Amussat's view on the relationship of the urinary tract with the prostate gland. Despite Pirogov's visual proofs Amussat kept disagreeing [52].

\section{Orthopaedic treatment: the transection of the Achilles tendon}

Nikolay Pirogov's first encounter with orthopaedic surgery was a 14-year-old female patient with a clubfoot [41]. Until then he was only aware of the specialty through the publications of the German surgeon Georg Friedrich Louis Stromeyer (1804-1876), a pioneer in orthopaedic surgery. In 1831 Stromeyer performed the first subcutaneous tenotomy of the Achilles tendon on a patient with a club foot $[26,59]$. Pirogov considered the operation of tenotomy, the transection of the Achilles tendon advocated by Stromeyer, as one possible treatment for his patient, although he thought it rather risky. Nonetheless he decided to proceed and cut the tendon. Fortunately the operation was successful. From what Pirogov read about the procedure in the available literature, no one had until then investigated by animal experiments the reason why the operation was successful, or what the exact consequences were of cutting the tendon. Thus in 1837 he began his own research into the anatomy of the Achilles tendon and changes induced by its transection.

From his research and his observations during operations on his patients Pirogov reported that the Achilles tendon was enclosed in a double sheath and not by a single one as 
previously thought. One is the aponeurotic sheath, - the continuation of the fascia cruris the other a peculiar cellular-synovial tissue. $\mathrm{He}$ believed that a satisfactory regeneration of the tendon following tenotomy appeared to require maintaining blood supply to and a thrombus was present in the tendon sheath. He published his results, which included seven plates with drawings, in 1840 [41]. He carried out 80 experiments using various species of animals and subsequently performed 40 tenotomies in humans, applying the knowledge he had learned from his animal experiments. Pirogov faithfully believed in impartial research and considered surgery to be successful only if the theory is firmly confirmed by experiments and anatomicalphysiological and pathological studies [41].

During his Dorpat time Pirogov published in total 14 books and articles and he supervised 12 doctorate students during his time as a professor in Dorpat [18].

\section{Pirogov as a forerunner, co-founder and Inspector-General of the Red Cross}

From its earliest beginnings the citizens of Russia demonstrated humanity and generosity towards victims of war and armed conflict, whether military or civilian [32].

Nikolay Pirogov first became involved in military surgery in 1847 during the Caucasian War, a consequence of a long-lasting Russian invasion (1817-1864) of the Caucasus. Tsar Nicholas I sent Pirogov to the warzone to demonstrate the use of the new technique of ether on the battlefield [42]. Pirogov and his colleagues treated Russian soldiers, Caucasian rebels and prisoners with equal care [14]. Because of '...his pioneering work in military medicine and surgery and his concern for the amelioration of the condition of the wounded and sick in armies in the field'[62]. Pirogov was named '.... forerunner in the struggle for humanitarian rules that was to result in the signature of the First Geneva Convention and the founding of a Red Cross Society in Russia' [62]. This was seven years before the Crimean War, and seventeen years before the Convention of Geneva [14].

\section{The Crimean War}

The large numbers of casualties and miserable conditions forced for organization of nursing care during the Crimean War (October 1853 to February 1856) [45,63]. Pirogov, remembered that he in 1837 in Paris saw how women were employed in hospitals to take care of patients. This inspired him also to develop a professional aid role for Russian women in the health care system [51].

The siege of Sevastopol was the final major battle during the Crimean War. The grounds around the city became the main battlefield, where the Russian army suffered huge losses. Pirogov requested to be sent there. Grand Duchess Elena Pavlovna, the sister-in-law of Tsar Nicholas I and aunt of Tsar Alexander II, interceded on his behalf with her brother-in-law. $\mathrm{He}$ then was appointed by Tsar Nicholas I as the overall head of the army medical services. Pirogov was convinced that successful treatment of mass casualties depended as much or even more on good management as on the skill of the surgeons [28, 45, 51]. In October 1854 Pirogov arrived in Sevastopol. The medical situation was catastrophic. Typhus patients, gangrene patients and patients, who had undergone surgery, were nursed adjacent to each other in the same rooms. He also noticed a severe shortage of virtually everything; beds, medical equipment, dressings and medication. Because of the large numbers of casualties, the major priority for Pirogov was to start as soon as possible a total management reorganization including, among other, treatment procedures and the nursing care $[45,51]$. The latter was something he and Grand Duchess Elena Pavlovna had discussed before Pirogov left for the Crimea [28].

In the autumn of 1854 Grand Duchess Elena Pavlovna founded, at her own expense, the Exaltation of the Holy Cross Community of nurses and appealed to Russian women to train as nurses to care for the wounded and the sick victims of the war. Her Mikhailovsky Palace in St. Petersburg became a military center and back office $[7,35]$. Pirogov and his team of doctors trained the volunteer nurses in the skills they would need [6, 43, 44]. In November 1854, the first group of nurses arrived in the Crimea, followed shortly thereafter by a regular flow of new female staff $[43,46]$. Most of the nurses were well educated, they spoke several languages and even interpreted for the wounded foreign prisoners [45].

By March 1855 Pirogov had enough nurses to allow him to take over the overall management of all first-aid posts and hospitals [45]. The female auxiliary staff became bandage masters helping surgeons; pharmacy assistants preparing drugs and supervising their distribution; and housekeepers taking care of clean linen and the sick. To deal with the massive influx of injured, Pirogov introduced the use of triage developed by the French military surgeon Dominique-Jean Larrey for the management of mass casualties. In the spring of 1855 , the fighting intensified and the management changes introduced by Pirogov now improved their worth $[42,45,51]$.

When Alexandre II, who had succeeded his father Nikolay in 1855 , visited the hospitals on the Crimea. In September 1855 he started peace negotiations and on 18 (30) March 1856 the peace treaty was signed in Paris. After the peace agreement the nurses received awards and returned they continued their nursing work in military hospitals $[6,51]$. 


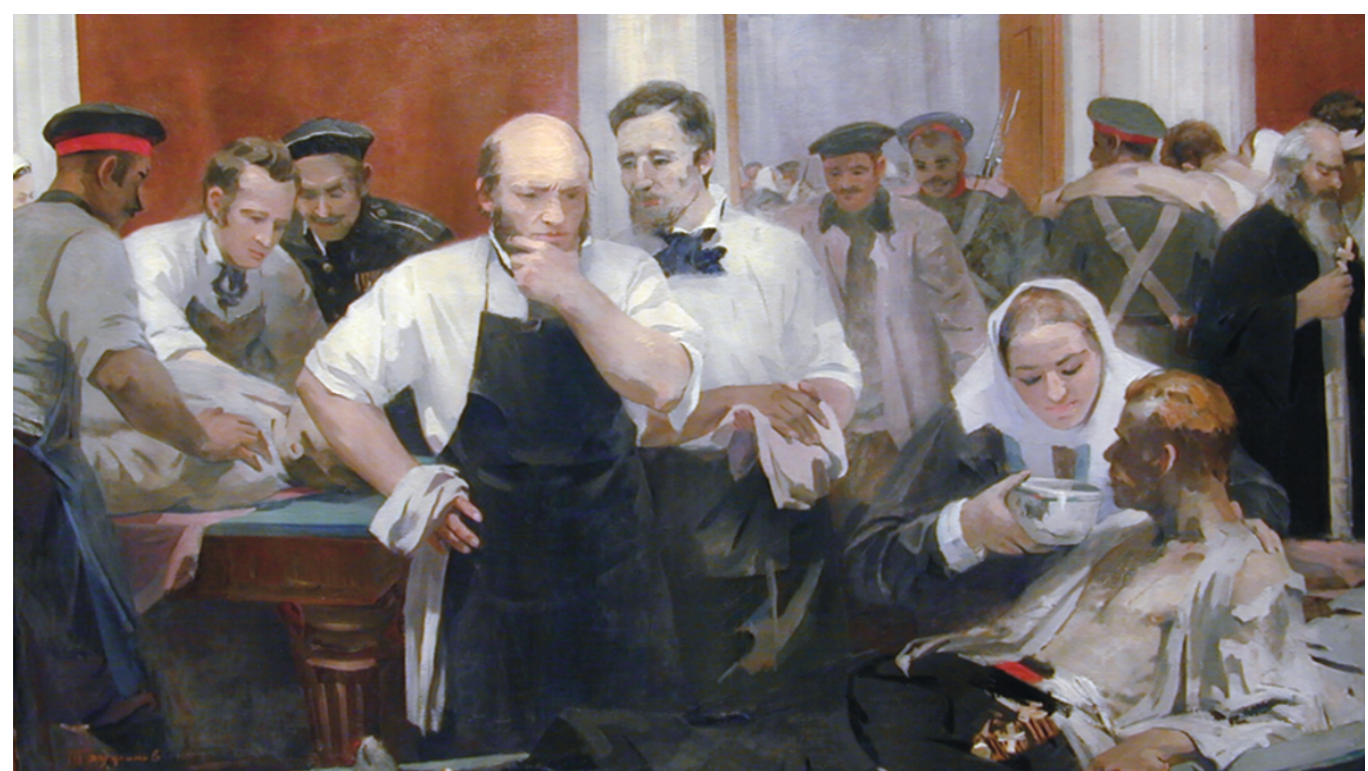

Fig. 2. N.I. Pirogov at the main dressing station 1855 at the Crimea. Oil on canvas, 1960, artist M.P. Trufanov. Image nr. 60743 PF. Reproduced with the permission from the Military Medical Museum of the Ministry of Defence of the Russian Federation, Saint Petersburg.

The French, Sicilians and the British also used women as nurses. The influential British newspaper The Times published news from the Crimean War, including details about the miserable conditions faced by the wounded and sick. Under pressure from the public, the Secretary of War, Sidney Herbert, asked nurse Florence Nightingale (1820-1910) to go to the Crimea to organize humanitarian aid to the wounded [17, 27, 63]. She arrived with the first group of thirtyeight not well-trained women in 1854 in Scutari (now Üsküdar). More groups arrived later. The British nurses never nursed on the battlefield nor treated the wounded of the enemy.

The quality of the care for the wounded by the Russian aid in the Crimea was recognized by Florence Nightingale. In her Subsidiary Notes as to the Introduction of Female Nursing into Military Hospitals in Peace and War published in 1858, she wrote 'It remains to mention the Russian system, which, as regards the organization of the duties of the "sisters" appeared to me by far the best I have known'[33]. In the House of Commons two army officers reported that Russian nurses had only insignificant duties in the hospitals on the battlefield. Nightingale corrected them and stated that '...the Russian system seems to be the only perfectly organized system of female attendants in military hospitals, that was developed in the Crimean War'[33]. She explained that the nurses were in charge of all that related to the bedside care of the patient. They received orders from the medical officer, attended him in his rounds, conferred with him afterward and communicated with the feldshers or dressers (Fig. 2). Nightingale stated that the Russian organization appeared to be the nearest approach to good organization she had ever encountered.
During the Crimean War Pirogov made a plea for an international treaty to guarantee the safety of volunteers who provided aid to war victims on the battlefield, regardless of rank or nationality $[7,27]$. Later, others would make similar pleas.

In 1863 , seven years after the end of the Crimean War, Pirogov wrote his (Broad guidelines for general war surgery, according to reminiscences from the wars in the Crimea and the Caucasus and the hospital practice) [45]. He waited so long with this publication as a result of his traumatic experiences in the war. Because war sentiments waved around in Europe, he felt compelled to write a book as a manual on war medicine and surgery as he had noticed '...that not only Russian doctors but also foreign doctors (German and American) did not know the $\mathrm{ABC}$ of surgery. And other publications did not justify the facts...' $[45,51]$. His book became the standard reference for the next ninety years and was widely considered to have made a major contribution to the organization of citizens who volunteered to assist with the casualties of war.

\section{Battle of Solférino 1859 as a tipping point}

Jean Henri (Henry) Dunant, a Swiss businessman, writer and social activist, published a book Un souvenir de Solférino [13], which was translated soon after its publication into many different language [10]. He describes his experiences and observations during the Battle of Solferino (1859). Finally he called for international treaties to guarantee the neutrality and protection of those involved in armed conflicts, whether military of civilian and including medical and nursing personnel. He put this as a question to his readers: '...Would it not be possible, in 
times of peace and quiet, to form relief societies to have care given to the wounded in wartime by zealous, devoted and thoroughly qualified volunteers...'[13].

This is what Pirogov and Grand Duchess Elena Pavlovna had achieved several years earlier during the Crimean War.

\section{People with political influence took up the plea for an international treaty}

Henry Dunant's book was sent to leading political, military figures and other influential individuals in Europe, including Elena Pavlovna. $\mathrm{He}$ also visited many of them to make them aware of the purpose of his proposed institution [10]. Henry Dunant several times met personally with De Semonov, counsellor to the Russian Court and even with Grand Duchess Elena Pavlovna [34]. She promised him to interest her nephew, Tsar Alexander II, about his idea. Dunant also met Queen of Württemberg, Olga Nikolaeva Romanova, daughter of Tsar Nicholas I and sister-in-law of Elena Pavlovna [12, 34]. Grand Duchess Olga was the first among all the princesses and queens, who turned the not yet realized idea of Dunant already in 1862 into an established foundation for human aid named 'Society for men and women' [34]. Both Grand Duchesses of the house of Romanov were in first or second line related to Duchies and Kingdoms in Europe. Their commitments in late 1862 and beginning 1863 influenced their relatives in Europe and accelerated the process.

In October 1863 the Committee of Five organized an international conference in Geneva (the first Geneva Convention) which effectively marked the launch of the Red Cross movement. It was attended by delegates from eighteen national governments plus representatives of German Johanniter Orden and three Swiss social institutions [9]. Russia was among the first countries to support the objectives of this conference. The Russian delegation included Captain Aleksander Kireyev, adjutant of Grand Duke Konstantin. Grand Duchess Elena Pavlovna sent her librarian, Essakov, as an observer to the conference [34].

On 29 October the proposals of the committee were approved. Soon after this conference many national Red Cross Societies were formed as well as the Russian Red Cross.

\section{The development of the Russian Red Cross}

The first meeting of the Russian Red Cross was organized on 14 December 1866 by F.Ya. Karel, court physician and privy councillor to the Tsar, and the baronesses M.P. Frederiks and M.S. Sabinin, ladies-in-waiting to the Tsarina [61]. On 15 December Tsarina Maria Aleksandrovna accepted the patronage of the Society. On 17 February 1867 Nikolay Pirogov was appointed as Privy Councillor to the Russian Red Cross and is mentioned together with the Tsarina in the minutes as one of the founders of the Society [61]. Tsar Aleksander II approved the final statute on 3 May 1867 [61]. In the same year Alexander II also signed the Geneva Convention. On Russia's initiative, an International Conference was convened in St. Petersburg in October 1868 [55].

\section{The Berlin Conference of the Committee of the International Red Cross (CIRC)}

The Berlin Conference took place from 10-14 (22-26) April 1869. The president of the Russian Red Cross, General Adjutant Aleksander Karlovich Baumgarten, was appointed secretary for the main committee [61]. Following on from the Berlin Conference the Russian Red Cross decided to send Nikolay Pirogov as their authorized representative to the Franco-German War in Alsace and Lorraine [61]. In September 1870, Nikolay Pirogov as official Inspector-General of the Russian Red Cross and the Russian Ministry of Internal Affairs left for the war zone in Alsace and Lorraine. He recorded his findings and conclusions in a Russian report to the Russian Red Cross (Report on the visit to the military-sanitary facilities in Germany, Lorraine, and Elsa in 1870) [44]. At the annual meeting of the Committee of the Russian Red Cross on 5 December 1870, it was unanimously approved to award Nikolay Pirogov with honorary membership as a token of their deep gratitude for his work on behalf of the Committee [61].

The Russian Red Cross was active both in Russia and abroad [29]. On 22 September 1877, the Russian Red Cross asked Nikolay Pirogov, now 67-year-old, to report on the Balkan War. Pirogov published a report in Russian within eight months after being delivered to the Red Cross and in German in 1882 (The warfare, the sanitation service, and the private aid on the battlefields in Bulgaria and the back of the operating Army 1877-1878) [48].

\section{Recognition of the role of Nikolay Pirogov}

The role of Nikolay I. Pirogov in the development of the International Red Cross was recognized by the Belgian Red Cross, by the International Red Cross, but also by his colleague physicians. In August 1897 the International Medical Congress awarded Nikolay Pirogov with a Memorial placed in front of the entrance of the medical faculty of Moscow University [4].

In 1898 Frédéric A. Ferrière (1848-1924), deputy to the Grand Council and vice-president of the International Committee of the Red Cross wrote in the Bulletin International des Sociétés de la Croix-Rouge [16], that '...in 1854 the Grand Duchess Helene Pavlovna sent a detachment of Sisters of Mercy to the Crimean War, led by the famous surgeon Pirogov for the many wounded of all nationalities, who had fallen under the walls of Sevastopol....' He also stated in the same journal '...that the idea of the Red Cross society has 
its cradle in Russia. That's where it was realized for the first time...'

\section{Conflicting Interest \\ No external funding or conflicting interests declared.}

\section{Acknowledgments}

The authors are grateful for the immense and generous help and support they received from Mrs. Liudmila B. Narusova, President of the Anatoly Sobchak Foundation, for allowing access to the archives and libraries of museums and of scientific institutes in Saint Petersburg. We are also very thankful to Prof. Dr. A.A. Budko, director of the Military Medical Museum and his staff, and to Prof. Dr. A.Ya. Fisun, general director of the Military Medical Academy in Saint Petersburg and his staff for their kind support and enthusiasm.

\section{References}

1. Adstrum $S$, Nicholson $H$. A history of fascia. Clinical Anatomy. 2019 Apr;32(7):862-70. doi: 10.1002/ca.23371

2. Anon. Cooper AP. The New Encyclopaedia Britannica. 1989.

3. Anon. Cooper AP. In: Chisholm H, ed. Encyclopaedia Britannica. Cambridge: Cambridge University Press; 1911.

4. Anon. Section: General Meeting. In: Roth W, ed. Minutes XII International Congress of Medicine. Moscow: I.N. Kouchnereff \& Cie; 1900.

5. Appleby $J H$. Ivan the Terrible to Peter the Great: British formative influence on Russia's medicoapothecary system. Medical History. 1983 Jul;27(3):289-304. doi: $10.1017 /$ soo25727300042976

6. Bakunina EM. Memories. Nurses of the Community of the Holy Cross. (1854-1860). Vestnik Evropy. 1898;4:511-56.

7. Bertenson JV. Nikolay Ivanovich Pirogov. Outline of his public activities as a professor, surgeon, writer and educator. From 24 May 1831 till 24 May 1881. Saint Petersburg: K. Rikker; 1881.

8. Bettany GT, Cooper AP. In: Stephen L, ed. Dictionary of National Biography. London: Smith, Elder \& Co.; 1887.

9. Boissier P. History of the International Committee of the Red Cross. From Solferino to Tsushima. Geneva, Henry Dunant Institute, 1985.

10. Bosscha $J$. The Red Cross. 's Gravenhage, De gebroeders van Cleef; 1867.

11. Chistovich $Y$. History.The first medical school in Russia. Saint Petersburg: Yakova Treya; 1883.

12. De Cazenove L. War and humanity in the nineteenth century. Lyon: Salut Public; 1869.

13. Dunant JH. Un souvenir de Solferino. Geneve: JulesGuillaume Fick; 1862.

14. Evrard E. A Report of the Russian military surgeon Pirogoff about a campaign in the war in the Caucasus (1847). Medical legal considerations. Annales de droit international medical. 1972:35-42.

15. Fearn $S W$. Case of Aneurysm of the arteria innominata and of the origin of the subclavian artery, treated by ligatire of the common carotid artery. London: The Lancet.; 1836-1837.
16. Ferriere FA. Revue trimestrielle de medicine militaire, medicine interne. Bulletin International des Societes de la Croix-Rouge. 1898;29:154-81.

17. Genschorek $W$. Sister Florence Nightingale, the triumph of humanity. Leipzig: BSB B.G. Teubner Verlagsgesellschaft, S. Hirsel Verlag Leipzig: 1990.

18. Geselevich $A M$. Scientific, literary and epistolary heritage of Nikolay Ivanovich Pirogov. In: prof. AN Bakulev, ed. Moscow: State Publisher of Medical Literature; 1956.

19. Haas LF. Francois Magendie (1783-1855). Journal of Neurology, Neurosurgery \& Psychiatry. 1994 Jun 1;57(6):692-692. doi: 10.1136/jnnp.57.6.692

20. Hendriks IF, Bovill JG, Boer F, Houwaart ES, Hogendoorn PCW. Nikolay Ivanovich Pirogov: a surgeon's contribution to military and civilian anaesthesia. Anaesthesia. 2014 Nov 4;70(2):219-27. doi: 10.1111/anae.12916

21. Hendriks IF, Bovill JG, van Luijt PA, Hogendoorn $P C$. Nikolay Ivanovich Pirogov (1810-1881): A pioneering Russian surgeon and medical scientist. Journal of Medical Biography. 2016 Mar 8;26(1):10-22. doi: 10.1177/0967772016633399

22. Hendriks IF, Bovil JG, Zhuravlev DA, Gaivoronsky $I V$, Boer F, Hogendoorn PCW. The role of Dutch representatives in the development of medicine in Russia from the 9th to the 13th century. Vestnik of Saint Petersburg University Medicine. 2019 Jun 25;14(1):49-57. 10.21638/11701/spbu10.2019.106

23. Hendriks IF, Bovill JG, Zhuravlev DA, Gaivoronskii $I V$, Boer F, Hogendoorn PCW. The development of Russian Medicine in the Petrine era and the role of Dutch doctors in this process. Vestnik of Saint Petersburg University Medicine. 2019 Nov 14;14(2):158-72. doi: 10.21638/spbu11.2019.208

24. Hendriks I, Zhuravloyv D, Bovill J, Boer F, Hogendoorn $P$. Women in healthcare in Imperial Russia: The contribution of the surgeon Nikolay I Pirogov. Journal of Medical Biography. 2019 Jan 14:1-10. doi: 10.1177/0967772018818049

25. Hendriks IF, Zhuravlev DA, Bovill JG, Boer F, Gaivoronskii IV, Hogendoorn PCW, et al. Nikolay Ivanovich Pirogov (1810-1881): Anatomical research to develop surgery. Clinical Anatomy. 2019 Nov 11;33(5):714-30. doi: 10.1002/ca.23493

26. Hernigou P, Gravina N, Potage D, Dubory A. History of club-foot treatment; part II: tenotomy in the nineteenth century. International Orthopaedics. 2017 Jul 22;41(10):2205-12. doi: 10.1007/s00264-017$3578-\mathrm{z}$

27. Kalamanov VA. The Emergence and Development of the Red Cross Movement in Russia. In: Durand RMJ, ed. Preludes and pioneers. Precursors of the Red Cross 1840-1860. Geneva: Society Henry Dunant; 1991.

28. Koni AO. Essays and memoires. (Public readings, speeches, articles and notes). Saint Petersburg: AC Suvorina; 1906.

29. Kuzionov $P V$. Participation of women in caring for the wounded and ill during the Crimean and RussoTurkish Wars. Med Sestra. 1988 Feb;47(2):47-50.

30. Kuzmin MK, Sorokina TS. Medicine in ancient Russia. Feldsher. Akush 1984;49:31-7.

31. Lazorthes G, Campan L. Francois Magendie (17831855). Bull Acad Natl Med. Jan-Feb 1984;168(12):105-11.

32. Likhachev DS. Tale of the Bygone Years. Here is the tale of the bygone years, where the Russian land came from, who in Kiev was the first ruler, and how the Russianland arose. Moscow-Augsburg: Im Werden Verlag: 2003.

33. McDonald L. Florence Nightingale on Wars and The 
War Office. Canada: Wilfrid Laurier University Press; 2011.

34. Müller $R$. History of the development of the Red Cross and the Geneva Convention with the support of its founder J.H. Dunant. Following a commemoration of Solferino by J. Henry Dunant, founder of the Red Cross and author of the Geneva Convention, and sections of his memoirs. Stuttgart: Druck und Verlag von Greiner \& Pfeiffer; 1897.

35. Nurses. A collection of letters of the nurses of the Holy Cross Society. The care for the wounded. 2nd ed. Saint Petersburg: Morskoy Sbornik; 1865.

36. Oborin NA. The first Centre for Higher Medical Education in Russia. (For the 280th anniversary of the Moscow hospital and the Moscow medical-surgical school - the Military Medical Academy named S.M. Kirov). Klin. Med (Mosk). 1990;68:118-21.

37. Pirogov NI. Is ligation of the abdominal aorta with an aneurysm of the groin a readily feasible and safe intervention? Dorpat, Livonia: JC Schenmann; 1832.

38. Pirogov NI. Surgical anatomy of the arterial trunks and the fibrous fasciae. 1 ed. Dorpat: CA Kluge; 1838.

39. Pirogoff NI. Uber die Moglichkeit der Unterbinding der Aorta abdominalis. Journal der Chirurgie und Augenheilkunde. 1838;27:122-46.

40. Pirogoff NI. Uber die Moglichkeit der Unterbinding der Aorta abdominal. Schluss. Journal der Chirurgie und Augenheilkunde. 1838;27:241-59.

41. Pirogov NI. About the intersection of the Achilles tendon as an operational-orthopaedic medicine. Dorpat: Franz Kluge; 1840.

42. Pirogov NI. Medical Report of a Journey to the Caucasus, containing statistical comparison of amputations, experimental research of firearms injuries, and a detailed description of the anaesthesia results, obtained on the battlefield and in different hospitals in Russia. 1 ed. Saint Petersburg: Printing House of the Journal of Saint Petersburg; 1849.

43. Pirogov NI. Continuation of news. About the nurses of the Holy Cross Community. Care for the wounded in the Crimea. Morskoy Sbornik. 1855;14:366-76.

44. Pirogov NI. Extract from the report, presented to Her Imperial Highness the Grand Duchess Elena Pavlovna, by professor Pirogov, on the activities of the nurses of the Holy Cross community and the doctors seconded to this community. Morskoy Sbornik. 1855;16:150-6.

45. Pirogov NI. Broad guidelines for general war surgery, according to reminiscences from the wars in the Crimea and the Caucasus and from the hospital practice. Leipzig: Verlag von F.C.W. Vogel; 1864.

46. Pirogov NI. Historical overview. Activities of the Holy Cross community, the care of the sisters for the sick and wounded in military hospitals in the Crimea and the Kherson oblast, form 1 December 1854 to 1 December 1855. Morskoy Sbornik. 1867;21:165-97.

47. Pirogov NI. Report on the visit to the military - sanitary facilities in Germany, Lorraine and Elsa in 1870 by N. Pirogoff. With permission of the author translated to German by N. Iwanoff, MD. Leipzig: F.C.W. Vogel; 1871.

48. Pirogov NI. The warfare, the sanitation service, and the private aid on the battlefields in Bulgaria and in the back of the operating Army 1877 - 1878. Translated from the Russian language by dr. Wilhelm Roth and dr. Anton Schmidt. 1 edn. Leipzig: Verlag von F.C.W. Vogel; 1882.

49. Pirogov NI. Collected Works in 8 Volumes. Volume I: Proceedings of Experimental and Clinical Surgery (1832-1840). Moscow: Gosudarstvennoe Izdatelstvo Meditsinskoy Literatury; 1957.

50. Pirogov NI, Zarechnak GV. Questions of life: diary of an old physician. Canton, Ma: Science History Publications, U.S.A; 1991.

51. Pirogov NI. Sevastopol letters. Saint Petersburg: Knigovek Knizhny Klub; 2011.

52. Pirogov NI. Questions of Life. Diary of an old physician, written exclusively for himself, but not without a second thought, that may be somewhere somebody will read it also. 5 November 1879 - 22 October 1881. Saint Petersburg: 2011.

53. Richter WM. History of Medicine in Russia. 1st ed. Vol. I. Moscow: N.S. Wsewolojsky; 1813.

54. Richter WM. History of Medicine in Russia. 1st ed. Vol. III. Moscow: N.S. Wsewolojsky, 1817.

55. Sorokina TS. History of Medicine. Moscow: Academia; 2008.

56. Shalaev SA. N.I. Pirogov - founder of the first hospital surgical clinic. Grekov's Bulletin of Surgery. 1991;146:130-2.

57. Shampo MA, Kyle RA. Francois Magendie: early French physiologist. Mayo Clin Proc; 1987:412.

58. Spasskiy IT. On plastic surgery in general, about rhinoplasty in particular. Lecture at the Imperial Saint Petersburg Academy of Science by N. Pirogov, $\mathrm{PhD}, \mathrm{MD}, 9$ december 1835. Voenno-Meditsinskiy Zhurnal. 1836;28:3-36.

59. Stromeyer GFL. Die Durchschneidung des Achillessehne, als Heilmethode des Klumpfusses, durch zwei Falle erlautert. Mag. ges. Hielk. (Rust). 1833;39:195.

60. Szymanowski J. Nicol. Pirogff's Surgical anatomy of arterial trunks and fascia with 50 drawings. Reedited by Julius Szymanovski. Leipzig und Heidelberg: C.F. Winter's Verlagshandlung; 1860.

61. Tupitsa IF. The Founding of the Russian Society of the Red Cross and the development of its activities in the period 1867-1875. (Systematic collection of materials). Kiev: Local Government Organization, The St. Vladimir University (I.I. Zavadskago); 1881.

62. Unknown. A note on N.I. Pirogov. International Review of the Red Cross Archive. 1974; 14:499-500.

63. Verdoorn JA. Physician and War. Medical and social care for military victims of war in the history of Europe. 2nd ed. Rotterdam: Erasmus Publishing; 1995.

Received 2.04.2020 Accepted 1.06.2020

Поступила в редакцию 2.04.2020

Принята в печать 1.06.2020

\begin{tabular}{|c|c|}
\hline $\begin{array}{c}\text { Поступила в редакцию 2.04.2020 } \\
\text { Принята в печать 1.06.2020 }\end{array}$ & $\begin{array}{l}\text { Received 2.04.2020 } \\
\text { Accepted 1.06.2020 }\end{array}$ \\
\hline \multicolumn{2}{|c|}{$\begin{array}{l}\text { Для цитирования: Hendriks I.F., Bovill J.G., Zhuravlev D.A., Boer F., Houwaart E.S., Hogendoorn P.C.W., Gaivoronskii } \\
\text { I.V. Highlights of the professional activities of Nikolay Ivanovich Pirogov before and after his professoriate in Saint } \\
\text { Petersburg (1841-1860). Part I. Журнал анатомии и гистопатологии. 2020; 9(2): 106-114. doi: 10.18499/2225-7357- } \\
\text { 2020-9-2-106-114 }\end{array}$} \\
\hline $\begin{array}{l}\text { For citation: Hendriks I.F., Bovill J.G., Zhure } \\
\text { Highlights of the professional activities of Niko } \\
\text { (1841-1860). Part I. Journal of Anatomy and H } \\
114\end{array}$ & $\begin{array}{l}\text { Hogendoorn P.C.W., Gaivoronskii I.V. } \\
\text { ter his professoriate in Saint Petersburg } \\
\text { doi: } 10.18499 / 2225-7357-2020-9-2-106-\end{array}$ \\
\hline
\end{tabular}

